DE- AI09-00SR22188 Journal Article $2010 \quad$ 10-09-P The Wilson Journal
of Ornithology

RED-COCKADED WOODPECKER MALE/FEMALE FORAGING DIFFERENCES IN YOUNG FOREST STANDS

KATHLEEN E. FRANZREB ${ }^{1}$

Published by the Wilson Ornithological Society

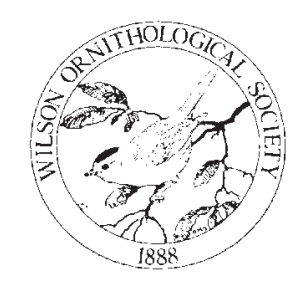




\title{
RED-COCKADED WOODPECKER MALE/FEMALE FORAGING DIFFERENCES IN YOUNG FOREST STANDS
}

\author{
KATHLEEN E. FRANZREB ${ }^{1}$
}

\begin{abstract}
The Red-cockaded Woodpecker (Picoides borealis) is an endangered species endemic to pine (Pinus spp.) forests of the southeastern United States. I examined Red-cockaded Woodpecker foraging behavior to learn if there were male/female differences at the Savannah River Site, South Carolina. The study was conducted in largely young forest stands $(<50$ years of age) in contrast to earlier foraging behavior studies that focused on more mature forest. The Redcockaded Woodpecker at the Savannah River site is intensively managed including monitoring, translocation, and installation of artificial cavity inserts for roosting and nesting. Over a 3-year period, 6,407 foraging observations covering seven woodpecker family groups were recorded during all seasons of the year and all times of day. The most striking differences occurred in foraging method (males usually scaled [45\% of observations] and females mostly probed [47\%]), substrate used (females had a stronger preference [93\%] for the trunk than males [79\%]), and foraging height from the ground (mean \pm SE foraging height was higher for males $[11.1 \pm 0.5 \mathrm{~m}]$ than females $[9.8 \pm 0.5 \mathrm{~m}]$ ). Niche overlap between males and females was lowest for substrate $(85.6 \%)$ and foraging height $(87.8 \%)$, and highest for tree species $(99.0 \%)$, tree condition $(98.3 \%)$, and tree height $(96.4 \%)$. Both males and females preferred to forage in older, large pine trees. The habitat available at the Savannah River Site was considerably younger than at most other locations, but the pattern of male/female habitat partitioning observed was similar to that documented elsewhere within the range attesting to the species' ability to adjust behaviorally. Received 24 March 2009. Accepted 9 November 2009.
\end{abstract}

The Red-cockaded Woodpecker (Picoides borealis), endemic to the pine (Pinus spp.) forests of the southeastern United States, is strongly associated with open, mature longleaf pine ( $P$. palustris) forest (USFWS 2003). Historically, this preferred habitat has been maintained by fire without which the hardwood midstory may develop to make the area unsuitable for Red-cockaded Woodpeckers. A reduction in the frequency of fire (Jackson 1986, Ligon et al. 1986, Walters 1990), loss of longleaf pine forests (Conner et al. 2001), and a general overall reduction in the age of forest stands resulting from short-rotation ages (Wahlenberg 1960, Frost 1993) have resulted in modification or loss of habitat throughout the geographic range of the species. Red-cockaded Woodpeckers are cooperative breeders living in social groups consisting of the mated pair and often one or more helpers, which are usually male and the offspring of one or both members of the breeding pair. They construct their own cavities in mature, living pine trees, which are used for nesting and night roosting (Jackson et al. 1979). This is a fairly long-lived species in which all individuals in the group cooperate in territorial defense, excavation of cavities, incubation, and feeding nestlings and fledglings (Hooper and Lennartz 1981). There is a long period of juvenile dependency, which Ligon

\footnotetext{
${ }^{1}$ USDA Southern Research Station, Department of Forestry, Wildlife, and Fisheries, University of Tennessee, Knoxville, TN 37996, USA; e-mail: franzreb@utk.edu
}

(1968) speculated was the result of the young having to learn specialized foraging techniques.

The Red-cockaded Woodpecker population at the Savannah River Site (SRS), South Carolina, had declined to a low of four individuals by 1986 at which time an intensive management effort was initiated to prevent extirpation of the species at the site. Results and details of the management program that was implemented are available in Franzreb (1997). Most forest stands on the site had been replanted with pine species when this study was initiated in 1992 and $\sim 92 \%$ of the pines were $\leq 40$ years of age (K. E. Franzreb, unpubl. data). Previous Red-cockaded Woodpecker studies on foraging and habitat use relied on areas that contained a fairly large proportion of older trees in contrast to the younger age and smaller size-class distribution patterns for trees at SRS where old, large diameter trees were sparse.

The Red-cockaded Woodpecker population at SRS is intensively managed including: removal of nest site competitors such as southern flying squirrels (Glaucomys volans) from cavities; translocations of woodpeckers from off-site locations to augment the population; translocations on-site to replace lost mates or establish new pairs; and research to examine habitat requirements, homerange size and configuration, and foraging behavior. All birds were monitored, nestlings were banded, and the reproductive rate was estimated for each group on an annual basis (Franzreb 1997). The Red-cockaded Woodpecker 
population increased on the site during the course of this study from 36 to 89 birds, including 21 translocated birds from off-site (Franzreb 1997, 1999).

Previous investigations by others were conducted in habitat largely consisting of stands with relatively mature trees, offering a more structurally complex vegetative environment with greater opportunities to partition the habitat than likely found in much younger forest stands. Further, most studies of Red-cockaded Woodpecker foraging behavior and habitat use have not differentiated observations by males and females; those that did noted differences in foraging behavior. Published studies have noted male/female variation in method of foraging, tree species selection, use of hardwoods, foraging height from the ground, foraging substrate, tree height selection, location, and tree condition (Skorupa 1979, Hooper and Lennartz 1981, Rudolph et al. 2007). However, Zwicker and Walters (1999) found no difference in foraging in relation to tree age, diameter at breast height, or species between male and female Red-cockaded Woodpeckers in the Coastal Plain of North Carolina. Porter and Labisky (1986) suggest that differing foraging requirements in different habitats necessitate habitat-specific forest management guidelines for Red-cockaded Woodpeckers.

The objectives of my study were to: (1) examine habitat partitioning between foraging male and female Red-cockaded Woodpeckers in a habitat that largely consisted of stands of trees that were considerably younger than most habitat found elsewhere in the range; (2) compare habitat availability with foraging use for males and females; (3) assess differences among groups in selection and preferences on the SRS; and (4) discuss the possible role younger forest stands may have in the range-wide management and conservation of the species.

\section{METHODS}

Study Area.-The Savannah River Site, a National Environmental Research Park, is in the Upper Coastal Plain Physiographic Region in Aiken, Allendale, and Barnwell counties, South Carolina, USA. Most of the land was acquired by the Department of Energy (DOE) in the late 1940s and early 1950 s to develop into a nuclear production facility. Most of the site was in agricultural use or recently had been harvested for timber prior to acquisition by DOE. The
USDA, Forest Service has managed the natural resources of the site for DOE since 1952. The area managed for woodpeckers during this study contained 31,970 ha of pine forest consisting of longleaf $(37.7 \%$ of the pine), loblolly ( $P$. taeda, $45.4 \%)$, slash (P. elliottii, 13.4\%), and other pines $(0.2 \%)$, in addition to pine-hardwoods (3.3\%) (Glenn Gaines, U.S. Forest Service, unpubl. data). Most of the existing pine stands are the result of replanting efforts undertaken in the 1950s, although there are some residual older pine trees. Approximately $92 \%$ of the pine trees were $\leq 40$ years of age (K. E. Franzreb, unpubl. data).

Foraging Data Collection.-Each Red-cockaded Woodpecker on the site was banded with a unique set of colored plastic leg bands for field identification and also with a numbered aluminum leg band provided by the U.S. Geological Survey. I obtained the necessary endangered species permits and banding permits from the U.S. Fish and Wildlife Service, U.S. Geological Survey, and State of South Carolina.

I selected seven groups of Red-cockaded Woodpeckers for observation on SRS based largely on their history of successfully breeding, increasing the likelihood the group would be present for the entire length of the study. Each group consisted of a breeding male and breeding female and often at least one helper. There was no turnover in either member of the breeding pair for two groups (groups 3 and 6). The male breeder also remained the same for three of the other groups (groups 1, 4, and 7). The breeding female varied from a group that had no turnover during the study, to changing every breeding season (group 2). Group composition during most years included at least one helper and there was no group that did not have a helper at least one of the years. The Red-cockaded Woodpecker population on the site during this study increased from 36 to 89 birds, including 21 translocated individuals from off-site (Franzreb 1997, 1999).

Foraging observations were obtained from 5 May 1992 to 26 July 1995. Each foraging observation consisted of: individual identification (band colors), date, time, tree species, tree height (m), tree condition (alive or dead), diameter at breast height $(\mathrm{dbh})(\mathrm{cm})$, tree age, foraging method, foraging substrate (trunk, live limb, dead limb, cone), foraging height from the ground (m), timber stand location (compartment and stand number), and weather conditions (percent cloud 
cover, wind conditions, precipitation). Tree age, height, and dbh are likely to be positively correlated. These three variables are included because forest managers use them in developing management plans and there is a large amount of variation depending on site quality and physiographic region. The location of each observation was defined using a global positioning system (GPS) Trimble Pathfinder Professional (use of brand names conveys no recommendation by the U.S. Forest Service). Observations were obtained for all members of the Red-cockaded Woodpecker groups. Data were collected during all seasons of the year and all times during the day. Birds were observed from the time of leaving the roost cavity in the morning and, if possible, until they returned to the cavity at night. Each bird located was followed until it made a foraging "strike" (defined as an actual attempt to collect prey) at which time the first observation was taken. At least 15 min separated sequential observations of the same individual to minimize inter-dependence of subsequent observations (Hejl et al. 1990). Porter et al. (1985) reported that a 15-min interval between sequential observations was sufficient for independence for Red-cockaded Woodpeckers. I accounted for possible correlation among observations of the same individual instead of relying on the informal 15 min rule.

Vegetation Data.-I used the Continuous Inventory of Stand Conditions (CISC) data base for information on stands such as dominant tree vegetation, stand age, and stand condition on the SRS (U.S. Forest Service, unpubl. data). A stand is a contiguous group of trees sufficiently uniform in age-class distribution, composition, and structure growing on a site of sufficiently uniform quality to be a distinguishable unit (Helms 1998). More detailed information was obtained by sampling vegetation in all stands within $800 \mathrm{~m}$ of the nest tree of each of the Red-cockaded Woodpecker groups studied. Most foraging observations occurred within $800 \mathrm{~m}$ of the nest tree of each group. Hardwood and pine trees in each stand were sampled using 0.04-ha fixed-radius plots established along transect lines at a rate of one plot per 2 ha of stand size following James and Shugart (1970). The beginning of each transect in a stand was established from a random point. Sample stations were separated by $50 \mathrm{~m}$ and transects were at least $50 \mathrm{~m}$ apart. The following variables were measured in each 0.04ha plot for every tree: tree species, tree height $(\mathrm{m})$, tree condition (alive, dying, or dead), diameter at breast height $(\mathrm{dbh})(\mathrm{cm})$, age (increment bore reading of 4,945 trees including 1,061 hardwoods and 3,884 pines or CISC for even-aged pine stands), location (compartment/stand/Red-cockaded Woodpecker group number), and specific plot location.

Statistical Analyses.-A randomized block experimental design was used with repeated observations where blocks are the Groups and treatment is Gender, which is tested with the Group*Gender interaction as the error term. Observations of each individual bird were represented as BirdID (individual band of a bird) and nested within each Group*Gender. This is equivalent to a randomized block repeated measures design where observations of a given bird follow a compound symmetry covariance matrix (common variance and common covariance). There were numerous observations of the same individual during the 3-year study period, often ranging to over 100 observations of certain individuals. I used Proc Mixed (SAS 2004) for analysis that considered nesting or clustering of repeated observations for a given bird. This weighted the observations of individual birds so those with high numbers of observations would not unduly influence the outcome and bias the results (Rao and Scott 1992). This ensured that error terms and variances would be calculated correctly, yielding valid tests of hypotheses. I obtained least-squares means (hereafter referred to as means) for all continuous variables (foraging height, tree height, tree dbh, and tree age) for males and females in each group and for all groups combined. I tested differences between means using an $F$-statistic based on the mixed model using Proc Mixed. Individuals with fewer than five observations over the 3-year period were deleted from the analysis, which affected the degrees of freedom. Groups with the highest number of observations tended to have the highest number of birds with observations of more than five and these groups had the largest degrees of freedom indicated by the denominator term. I examined each group separately as well as combining data for all males and for all females. The amount and distribution of the habitat described by the variables studied differed within the home ranges of each group. Comparisons of the data on a per group basis provide a more complete representation of the range of foraging behavioral differences for males and females. 
I combined all observations of all pine trees regardless of species and then grouped them by age, height, and dbh class interval to allow for comparison of the distribution of observations for the continuous tree variables by gender. Tree height and foraging height data were grouped by $3-\mathrm{m}$ intervals. Age class data were grouped into 10 -year intervals. There were few observations in trees $<30$ years of age and the age class intervals $<30$ were grouped. Tree dbh data were grouped by $5-\mathrm{cm}$ size class intervals. The distribution of observations of males versus females was compared for these variables as well as for the other categorical variables (method, substrate, tree species, and tree condition) using the $F$-statistic in the Rao-Scott modified likelihood ratio test as obtained from Proc SurveyFreq (SAS 2004) for each group, and for males and females of all groups combined. This considered the nesting of the repeated observations for a bird in much the same way as the mixed model did using Proc Mixed for the other continuous variables. The Rao-Scott modified likelihood ratio test uses the survey design to adjust the typical Pearson Chisquare test by dividing the $P$-value by the survey design effect. The $F$-statistic used is an additional modification that provides a better statistic as suggested by SAS (2004). Degrees of freedom varied depending on the number of categories compared. Any cells with fewer than five observations were merged for these tests with the closest adjoining cell until there were at least five observations. The clustering process in the Rao-Scott tests also affected degrees of freedom.

I examined tree composition within an 800-m radius circle with a group's nest tree as its center. The value of $800-\mathrm{m}$ was selected because it was the same radius used by USFWS in its recommended foraging guidelines for this species. I estimated how many pine and hardwood trees of specific ages, heights, and dbh were available within each of these stands or portions thereof using the 0.04-ha plot vegetation information. I then estimated the availability of the resources (tree species, tree heights, dbh, and tree age) within the $800-\mathrm{m}$ radius circle. These availability data were used to derive estimates of how many observations were expected to occur if birds were using the foraging resources randomly. ArcInfo coverages were used to aid in this process. The percent use by each gender in each Red-cockaded Woodpecker group of pine trees by tree species and by tree age, tree height, and dbh class intervals was compared to expected use based on availability of these trees within the 800-m radius circle. Males and females in each group, and all males versus all females combined were compared with respect to the distribution of actual observations versus the number of observations expected. Expected values were based on resource availability within $800 \mathrm{~m}$ of the nest tree and these comparisons were used to examine any preference or avoidance of foraging resources. Any cells that contained $<5$ observations were either deleted or grouped with similar cells so the overall number of observations in each cell was $>5$.

I compared means for tree age and dbh for each pine species for trees that were available in the habitat of each of the groups and overall for all groups combined using Proc GLM and the Bonferroni adjustment for multiple comparisons (SAS 2004). All F-tests and comparisons of means were performed at the 0.05 significance level. Values reported are means $\pm \mathrm{SE}$.

I used Levin's (1968) measure of niche breadth where $\mathrm{B}=1 / \Sigma p^{2}{ }_{i}$ and $p_{i}$ is the proportion of observations recorded in class " $i$." I followed Schoener (1970) to estimate niche overlap for each variable: $\%$ overlap $=100\left(1-0.5 \Sigma \mid P_{x, i}-\right.$ $\left.P_{y, i}\right)$ where $P_{x, i}$ and $P_{y, i}$ are the respective frequencies for males and females in each class for a given type of behavior. An overlap of $100 \%$ indicates that males and females acted identically in regard to the type of behavior examined, whereas $0 \%$ overlap indicates completely nonoverlapping behavior.

\section{RESULTS}

There were 6,407 foraging observations of all seven groups ranging from a low of 794 in group 7 to a high of 1,152 in group 2. Observations of males $(n=3,769)$ ranged from 403 in group 7 to a high of 576 in group 6 . Observations of females ( $n$ $=2,638$ ) ranged from 269 (group 4) to 502 (group 2).

Method of Foraging.-Scaling was the most commonly used foraging method for males in all seven groups, ranging from 40 to $52 \%$ of the total observations ( $n=3,769$; Fig. 1 ), followed closely by probing. However, females in five of the seven groups used probing more commonly than scaling $(n=2,638$; Fig. 1$)$. Foraging method significantly differed between males and females for all groups combined, primarily because females tended to probe more $\left(F_{3,297}=2.89, P=0.04\right)$. 


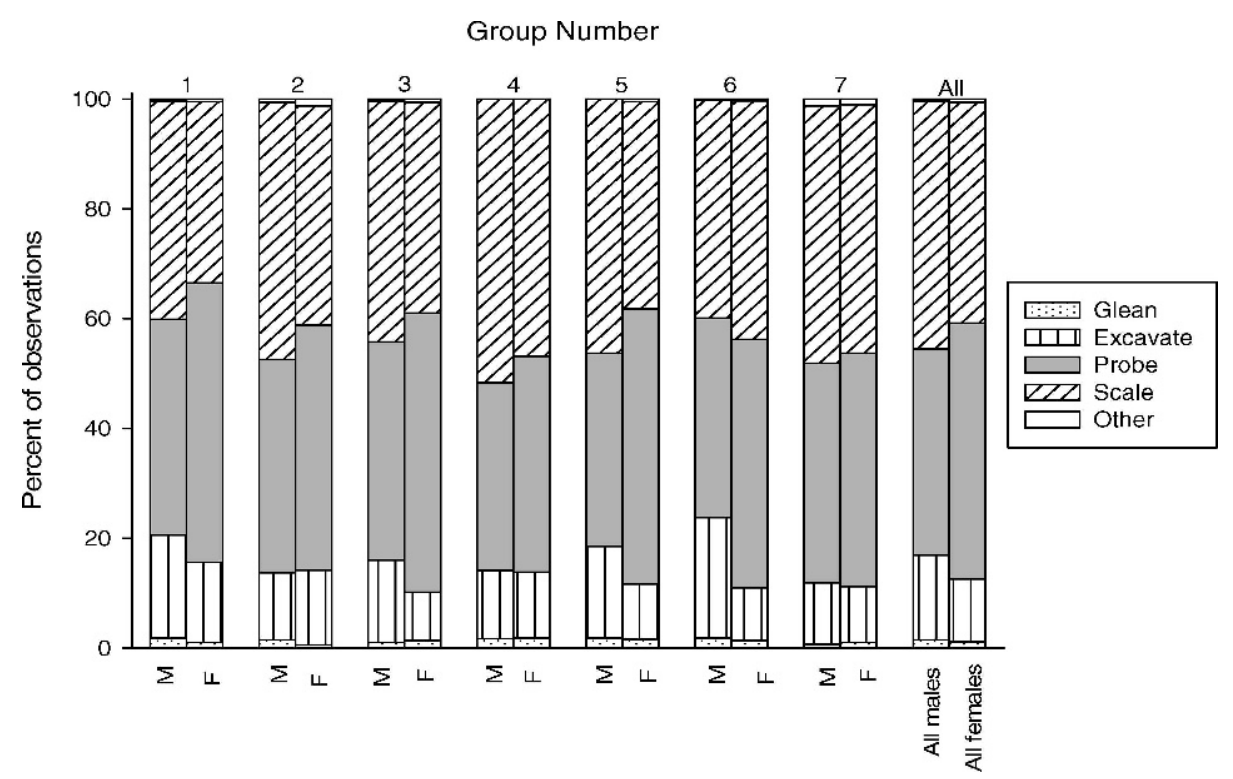

FIG. 1. Foraging method of male and female Red-cockaded Woodpeckers at the Savannah River Site, South Carolina, 1992-1995.

Substrate.-Males strongly preferred the trunk as the foraging substrate with 73 to $87 \%$ of observations occurring there (Fig. 2). For all groups combined, $79 \%$ of all male foraging was on the trunk surface, followed by $10 \%$ on a live limb, and $11 \%$ on a dead limb (Fig. 2). Females in each group had a stronger preference for foraging on the trunk than males and used that surface a minimum of $87 \%$ of the time (Fig. 2). Overall, $93 \%$ of all female foraging observations were on the trunk, followed by $4 \%$ on a live limb, and $2 \%$ on a dead limb. Occasionally males and females were observed foraging on cones (19 instances for males, 7 instances for females), and there was one instance of a female foraging on the ground. There was a significant difference in foraging substrate selection in every group and for all groups combined between males and females (all $F$ values $\geq 3.79$, all $P \leq 0.03$ ).

Tree Species Selection.-At least $98 \%$ of all foraging by males and females, regardless of group, occurred in pine trees. Overall for males there were $27(0.7 \%)$ instances and up to $1 \%$ of observations for groups foraging in hardwood trees. Females were observed foraging in hardwoods on 20 instances $(0.8 \%)$ and $2 \%$ of observations by group.

There was a decided preference by both males and females to forage in longleaf pines and this did not seem to be the result of tree dbh or age.
The mean overall dbh values for pine species showed that, on average, longleaf pine trees available at SRS were $1.0 \mathrm{~cm}$ larger than loblolly pines and $2.8 \mathrm{~cm}$ larger than slash pine trees. Mean tree age of longleaf pine exceeded that of loblolly pine by 0.6 to 8.5 years but, in some groups, the mean age of the available loblolly pines exceeded that of longleaf by 0.3 to 5.0 years. For example, in group 1, loblolly pines on average were bigger (larger dbh) and older than longleaf pines. The latter species was most frequently used for foraging by males in all groups (range 69 to $90 \%$ ) and accounted for $79 \%$ of all male observations $(n=3,743)$. Females also preferred to forage in longleaf pine trees, in which $78 \%$ of observations occurred (range $62-94 \%$ in the 7 groups). Loblolly and slash pine also were used, but to a much less extent. There was a significant difference in tree species selection by males and females in two of the seven groups $(F$ values $\geq$ 4.60, $P$ values $<0.02$ ); however, considering all male and female observations combined, there was no significant difference in tree species selection $\left(F_{2,196}=0.11, P=0.91\right)$.

Tree species selection by males differed from expected on the basis of tree species availability in all groups and for all males combined (all $F \geq$ 4.23, all $P \leq 0.04$ ). Females in all but group 2 did not use tree species in the same proportion as available (all $F \geq 4.79$, all $P \leq 0.03$ ). Males in all 


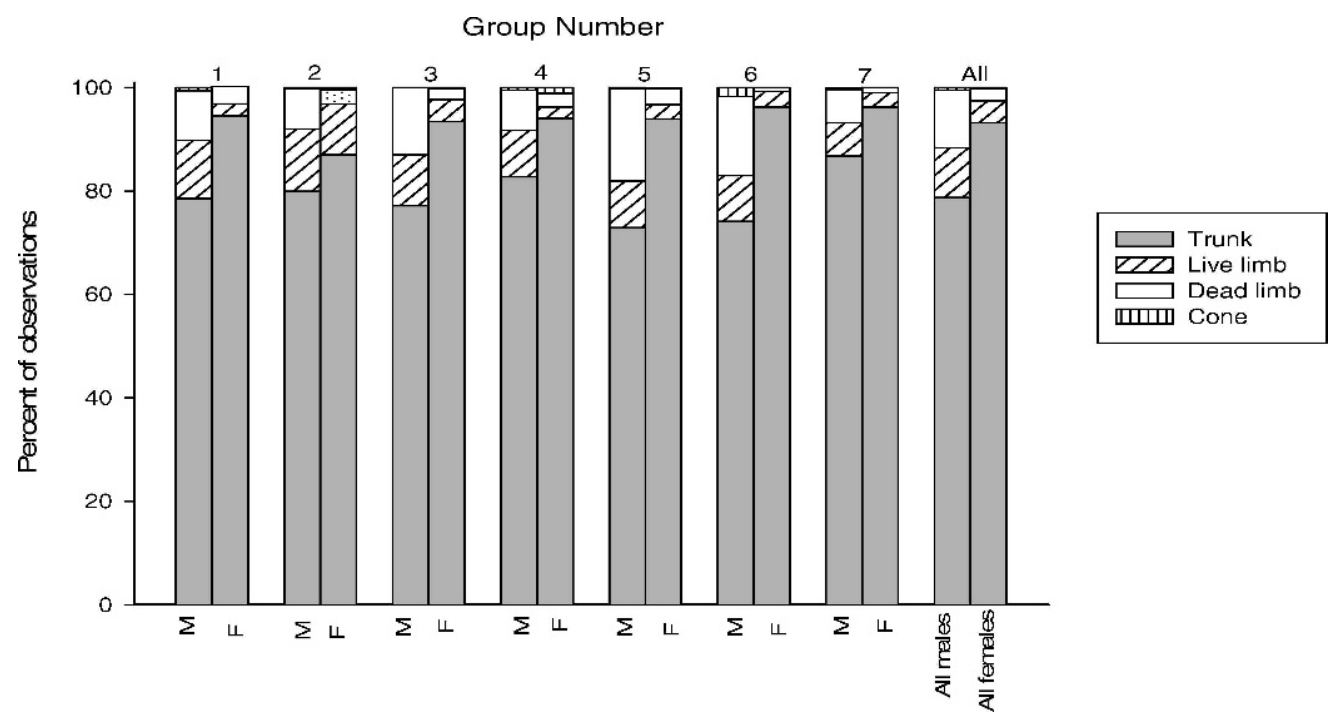

FIG. 2. Substrates used by foraging male and female Red-cockaded Woodpeckers at the Savannah River Site, South Carolina, 1992-1995.

groups and females in five of the seven groups foraged more in longleaf pines than expected based on availability.

Foraging Height.-Mean foraging height of males ranged from $9.5 \pm 0.6 \mathrm{~m}$ in group 1 to 12.7 $\pm 0.4 \mathrm{~m}$ in group 5 (Table 1). Mean foraging height of females ranged from $7.5 \pm 0.5 \mathrm{~m}$ in group 1 to $11.8 \pm 0.4 \mathrm{~m}$ in group 5 (Table 1). Mean foraging height for males in two groups was higher than for females $(F \geq 6.0, P \leq 0.03$; Table 1). Foraging height for males for all groups combined was higher $(11.1 \pm 0.5 \mathrm{~m})$ than for females $\left(9.8 \pm 0.5 \mathrm{~m} ; F_{1,6}=17.67, P=0.006\right.$; Table 1).

Tree Height.-Mean heights of trees selected for foraging by males ranged from $17.6 \pm 0.6 \mathrm{~m}$ in group 1 to $21.5 \pm 0.3 \mathrm{~m}$ in group 5 . Mean tree height selection by females ranged from $17.1 \pm$ 0.6 to $21.3 \pm 0.3$ for groups 1 and 5 , respectively. Mean tree height selection for all male observations combined $(19.6 \pm 0.5 \mathrm{~m})$ was not different than for females $\left(19.6 \pm 0.5 \mathrm{~m} ; F_{1,6}=0.02, P=\right.$ 0.90). There was no difference in mean tree heights between males and females in five of the seven groups (all $F \leq 0.42$, all $P \geq 0.53$ ) or between males and females within any group $(F$ $\geq 4.49, P>0.05$ ).

There was no difference for five of the groups comparing the distribution of observations for male versus female tree height selection (all $F \leq$ 1.39 , all $P \geq 0.24$ ). Nor was there a difference between males and females for all groups combined in distribution of observations by tree height $\left(F_{7,693}=0.28, P=0.96\right)$.

Males and females in every group and for all groups combined did not randomly select trees by height (all $F \geq 10.56$, all $P \leq 0.001$ ). Both males and females avoided shorter trees (those less than $12 \mathrm{~m}$ ), either avoided or used in proportion to availability mid-sized trees $(12-18 \mathrm{~m})$, and strongly preferred trees $>18 \mathrm{~m}$ in height.

Tree Condition.-Both males and females heavily foraged on live trees (average of $90 \%$ of male and $91 \%$ of female foraging observations). There was no difference in selection of trees by condition (alive, dead, or dying) between males and females in five of the groups and for all groups combined ( $F \leq 2.33, P \geq 0.12$ ). There was a difference between males and females in two groups $\left(F_{2,34}=6.06, P=0.006 ; F_{1,12}=53.2, P\right.$ $<0.0001$; groups 2 and 7 , respectively) and males in both groups used dying trees more than females.

Diameter at Breast Height (dbh). - There was a difference in mean diameter at breast height of trees selected by males versus females for two of the seven groups. Females in group $6\left(F_{1,14}=\right.$ $6.23, P=0.03)$ and group $7\left(F_{1,11}=9.22, P=\right.$ $0.01)$ selected trees with larger dbh than males. Overall, there was no difference in mean dbh of trees selected for foraging by males and females in all groups combined $\left(F_{1,6}=0.39, P=0.55\right)$. 
TABLE 1. Foraging height $(\mathrm{m})$ of male and female Red-cockaded Woodpeckers by seven groups and all groups combined at the Savannah River Site, South Carolina, 1992-1995.

\begin{tabular}{|c|c|c|c|c|c|c|c|c|}
\hline \multirow[b]{3}{*}{ Foraging height } & \multicolumn{8}{|c|}{ Percent observations } \\
\hline & \multicolumn{2}{|c|}{ Group 1} & \multicolumn{2}{|c|}{ Group 2} & \multicolumn{2}{|c|}{ Group 3} & \multicolumn{2}{|c|}{ Group 4} \\
\hline & M & $\mathrm{F}$ & M & $\mathrm{F}$ & M & $\mathrm{F}$ & M & $\mathrm{F}$ \\
\hline$<3$ & 4.9 & 16.1 & 5.7 & 13.0 & 2.3 & 9.1 & 4.7 & 10.4 \\
\hline$\geq 3-6$ & 13.5 & 23.2 & 15.1 & 14.3 & 8.9 & 16.5 & 10.3 & 17.8 \\
\hline$\geq 6-9$ & 25.8 & 25.7 & 22.0 & 16.9 & 16.9 & 18.2 & 20.0 & 21.6 \\
\hline$\geq 9-12$ & 26.4 & 14.9 & 21.7 & 20.5 & 23.0 & 16.2 & 24.7 & 20.1 \\
\hline$\geq 12-15$ & 18.4 & 13.4 & 16.6 & 16.1 & 27.3 & 17.6 & 16.1 & 15.2 \\
\hline$\geq 15-18$ & 7.4 & 5.5 & 10.8 & 11.6 & 16.2 & 15.6 & 14.6 & 7.4 \\
\hline$\geq 18-21$ & 2.2 & 1.0 & 5.9 & 6.6 & 4.6 & 5.4 & 6.9 & 5.6 \\
\hline$\geq 21-24$ & 0.8 & 0.0 & 1.2 & 0.2 & 0.7 & 1.1 & 1.7 & 1.5 \\
\hline$\geq 24$ & 0.2 & 0.0 & 0.5 & 0.0 & 0.0 & 0.3 & 0.7 & 0.4 \\
\hline Ground or no data & 0.4 & 0.3 & 0.6 & 0.8 & 0.0 & 0.0 & 0.3 & 0.0 \\
\hline Sample size & 509 & 398 & 646 & 500 & 561 & 352 & 589 & 269 \\
\hline LSMeans \pm SE & $9.5 \pm 0.6$ & $7.5 \pm 0.5$ & $10.4 \pm 0.3$ & $9.8 \pm 0.3$ & $11.7 \pm 0.7$ & $9.0 \pm 0.8$ & $11.1 \pm 0.5$ & $9.6 \pm 0.7$ \\
\hline \multirow[t]{15}{*}{$F$ value $^{\mathrm{a}}$} & \multicolumn{2}{|c|}{$\begin{array}{r}F_{1,11}=6.54 \\
P=0.03\end{array}$} & \multicolumn{2}{|c|}{$\begin{aligned} F_{1,16} & =1.67 \\
P & =0.21\end{aligned}$} & \multicolumn{2}{|c|}{$\begin{aligned} F_{1,13} & =6.00 \\
P & =0.03\end{aligned}$} & \multicolumn{2}{|c|}{$\begin{aligned} F_{1,14} & =3.00 \\
P & =0.10\end{aligned}$} \\
\hline & \multicolumn{2}{|c|}{ Group 5} & \multicolumn{2}{|c|}{ Group 6} & \multicolumn{2}{|c|}{ Group 7} & \multicolumn{2}{|c|}{ All groups combined } \\
\hline & M & $\mathrm{F}$ & M & $\mathrm{F}$ & M & $\mathrm{F}$ & M & $\mathrm{F}$ \\
\hline & 1.9 & 6.2 & 7.8 & 13.4 & 3.2 & 12.0 & 4.5 & 11.5 \\
\hline & 3.4 & 8.5 & 14.8 & 22.6 & 9.2 & 14.3 & 11.0 & 16.3 \\
\hline & 11.5 & 14.7 & 17.4 & 14.7 & 22.3 & 20.5 & 19.5 & 18.8 \\
\hline & 23.9 & 23.9 & 22.7 & 20.6 & 26.1 & 20.0 & 23.9 & 19.5 \\
\hline & 32.1 & 23.2 & 20.3 & 15.1 & 20.1 & 15.9 & 21.3 & 16.8 \\
\hline & 18.5 & 15.6 & 10.8 & 9.6 & 10.7 & 9.2 & 12.7 & 10.9 \\
\hline & 6.5 & 5.8 & 5.4 & 3.1 & 6.5 & 5.9 & 5.4 & 5.0 \\
\hline & 1.1 & 0.5 & 0.4 & 1.0 & 1.7 & 2.3 & 1.1 & 0.7 \\
\hline & 0.2 & 0.0 & 0.2 & 0.0 & 0.3 & 0.0 & 0.3 & 0.1 \\
\hline & 1.1 & 1.6 & 0.4 & 0.0 & 0.0 & 0.0 & 0.4 & 0.4 \\
\hline & 472 & 428 & 575 & 292 & 402 & 390 & 3,754 & 2,629 \\
\hline & $\begin{array}{r}12.7 \pm 0.4 \\
F_{1,13} \\
P=\end{array}$ & $\begin{aligned} & 11.8 \pm 0.4 \\
= & 2.38 \\
= & 0.15\end{aligned}$ & $\begin{array}{r}10.5 \pm 0.6 \\
F_{1,14}= \\
P=\end{array}$ & $\begin{aligned} & 9.4 \pm 0.8 \\
= & 1.22 \\
= & 0.28\end{aligned}$ & $\begin{array}{r}11.9 \pm 0.9 \\
F_{1,11}= \\
P=\end{array}$ & $\begin{array}{l}10.8 \pm 0.84 \\
=0.78 \\
=0.40\end{array}$ & $\begin{array}{r}11.1 \pm 0.5 \\
F_{1,6}= \\
P=\end{array}$ & $\begin{array}{l}9.8 \pm 0.5 \\
17.67 \\
0.006\end{array}$ \\
\hline
\end{tabular}

${ }^{\mathrm{a}} F$ and df values from Proc Mixed model; Note for $\mathrm{df}$ of $\mathrm{x}$ and $\mathrm{y}$ as given in $F_{\mathrm{x}, \mathrm{y}}, \mathrm{x}$ represents $k-1$ and $y$ is calculated by the clustering program.

There was a difference between males and females in two of the groups when comparing tree selection by distribution of observations by dbh size class with females using trees with larger $\mathrm{dbh}$ (group $6, F_{7,105}=3.78, P=0.001$; and group $\left.7, F_{7,84}=5.39, P<0.0001\right)$. There were no male/ female differences in distribution of observations for dbh size class intervals in the other five groups and for all groups combined (all $F$ values $\leq 1.31$, $P \geq 0.26$ ).

Males and females did not randomly select trees on the basis of dbh (all $F \geq 9.68$, all $P \leq$ 0.001). Both males and females avoided foraging in trees $\leq 20 \mathrm{~cm} \mathrm{dbh}$ and displayed strong preferences for the moderate and larger dbh size classes.
Longleaf and loblolly pine trees were the two most common pine species in the habitat. The mean dbh for longleaf pine trees available to three groups was higher than for loblolly pine (Table 2); however, loblolly pine for two groups had higher mean dbh values (all $P<0.001$ ). There was no difference in mean dbh values between longleaf and loblolly pine trees in the remaining two groups (Table 2). The available longleaf pines had a higher mean dbh (longleaf pine $=$ $17.9 \pm 0.2 \mathrm{~cm}$ vs. loblolly pine $=16.8 \pm 0.2 \mathrm{~cm}$, $P=0.004$; Table 2) for all groups combined.

Tree Age. - Females in group 5 (mean $=39.9$ \pm 0.2 years vs. mean $=39.3 \pm 0.2$ years; $F_{1,13}=$ 5.27, $P=0.04$ ) foraged more on older trees than males (Table 3). There was no difference between 


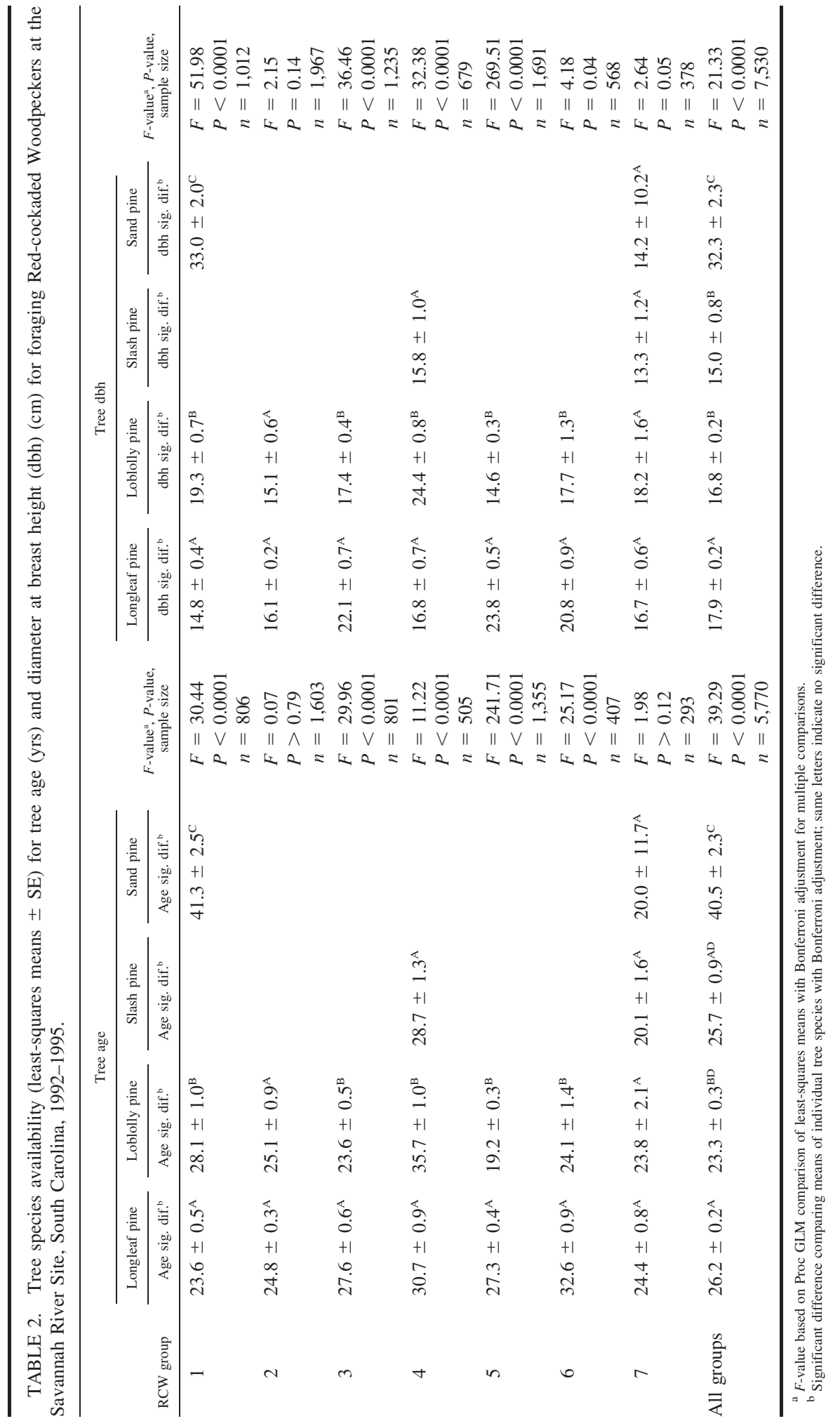




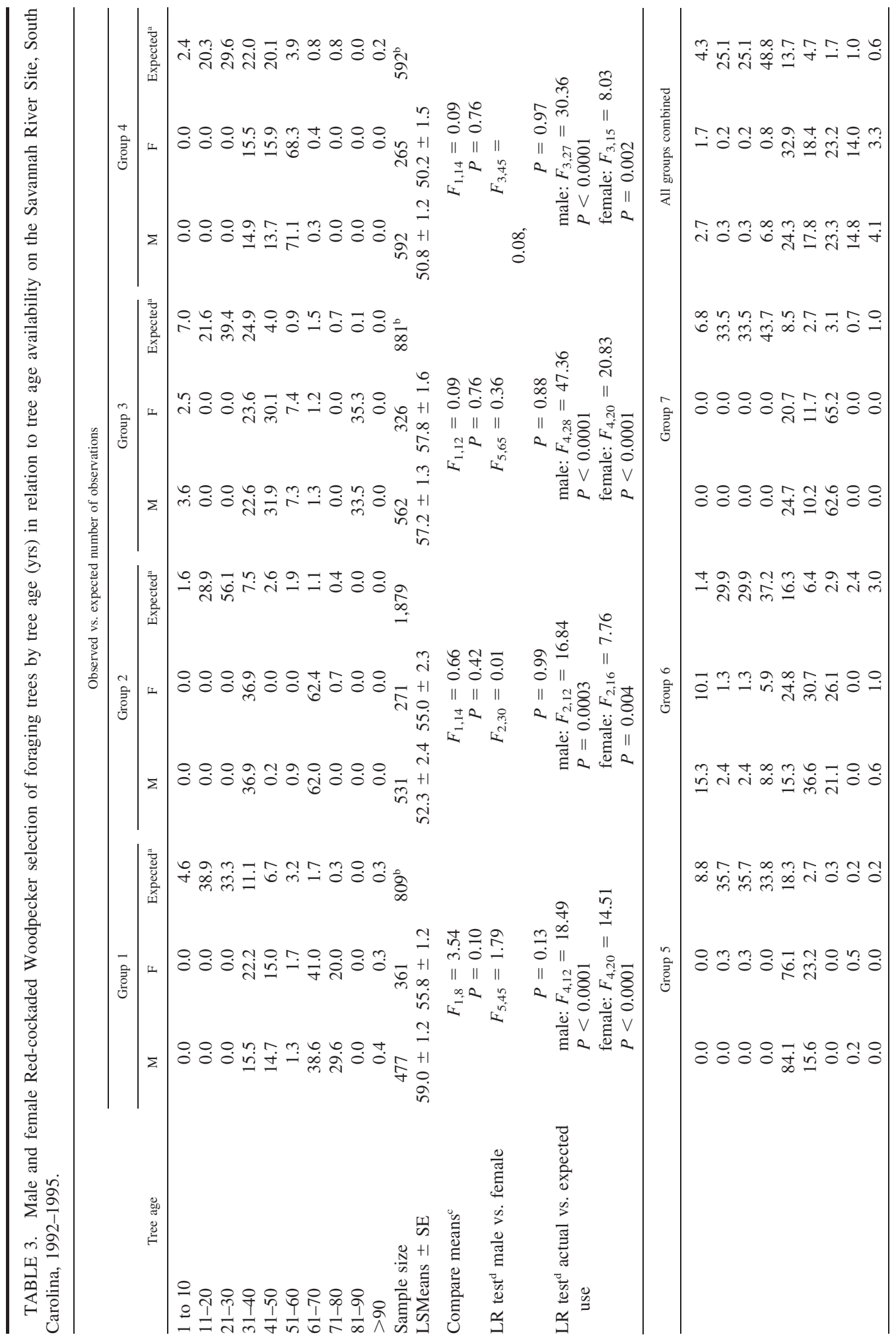


males and females for six of the seven groups and for all groups combined in tree age classes (all $F$ $\leq 1.79$, all $P \geq 0.13$, Table 3 ). Neither males nor females randomly selected trees by age class (all $F \geq 4.25$, all $P \leq 0.002)$. Both males and females used younger trees $(<30$ years of age) less than expected and preferred trees $\geq 30$ years of age (Table 3).

Mean age was higher for longleaf pine than loblolly pine in three groups $(P<0.0001)$ within the $800-\mathrm{m}$ radius circles centered on the nest tree of each group with the reverse true in two groups $(P<0.0001$; Table 2$)$. There was no difference in mean age between available longleaf and loblolly pines in groups 2 and 7 (Table 2). Mean tree age of longleaf pine $(26.2 \pm 0.2$ years) was higher compared to loblolly pine $(23.3 \pm 0.3$ years, $P<$ 0.0001 ; Table 2) combining the $800-\mathrm{m}$ circles of all groups.

Niche Breadth and Overlap.-Foraging variables that had the narrowest niche breadth were the same for males and females: tree species selection (1.54 vs. 1.57), tree condition (1.24 vs. $1.20)$, and substrate (1.56 vs. 1.15). Both males and females were most generalized in tree dbh (6.25 vs. 6.54), foraging height (5.78 vs. 6.41), tree height (4.85 vs. 4.91$)$, and tree age (5.55 vs. 4.55). Niche overlap between males and females was $\geq 90 \%$ for foraging method $(90.8 \%$ ), tree species $(99.0 \%)$, dbh $(95.7 \%)$, tree height $(96.4 \%)$, tree condition $(98.3 \%)$, and tree age $(90.9 \%)$. The least overlap between males and females was for substrate $(85.6 \%)$ and foraging height $(87.8 \%)$.

\section{DISCUSSION}

Results of foraging ecology studies of male and female Red-cockaded Woodpeckers in regard to foraging method have not been consistent (Ramey 1980, Hooper and Lennartz 1981, Rudolph et al. 2007). In my study, males scaled more than females in two groups, whereas females engaged more in probing. Red-cockaded Woodpeckers at SRS did not forage by excavating to the same extent observed at other locations, all of which had more mature pine habitat. It may be that young stands at SRS did not provide the deep, furrowed bark of older trees that would encourage more excavation. Culmen length is significantly longer in males than females (Mengel and Jackson 1977), which may contribute to the differences that have been observed. However, the Redcockaded Woodpecker is one of the least sexually 
dimorphic species of Picoides and, although difference in beak size could be an adaptation for differential foraging behavior, culmen length would seem to be insufficient to obviate the need to have other means to reduce intraspecific competition.

It has been reported that both males and females forage mostly on the trunk (Ligon 1968, Skorupa 1979, Ramey 1980, Hooper and Lennartz 1981). My results showed that males spent more time foraging on limbs than females, whereas females more frequently foraged on trunks. Ramey (1980) found variation in foraging site was the main difference between males and females, and there was substantial foraging in hardwoods, particularly by males. Pizzoni-Ardemani (1990) reported that male Red-cockaded Woodpeckers have longer beaks, toes, and legs, and shorter tails than females, which may be advantageous when clinging to branches and twigs on limbs. The shorter legs and longer tail of females may be beneficial when foraging on trunks (Pizzonni-Ardemani 1990), the common female foraging substrate.

Red-cockaded Woodpeckers forage on living pine trees and rarely use non-pine substrates (Ligon 1968, Hooper and Lennartz 1981, DeLotelle et al. 1983, Porter and Labisky 1986); however, DeLotelle et al. (1983) also found that $10 \%$ of foraging occurred in pond cypress (Taxodium ascendens) stands. Both males and females at SRS heavily used pine trees and at least $98 \%$ of all observations occurred there, similar to that reported by other studies (Ramey 1980; Zwicker and Walters 1999; Walters et al. 2000, 2002; Rudolph et al. 2007). I detected no difference between males and females in four of the groups and in all groups combined in use of different pine species. However, based on availability, both males (all groups) and females (5 of 7 groups) foraged in longleaf pine trees more than expected. Previous work on tree species selection produced conflicting results as to whether Red-cockaded Woodpeckers prefer a particular pine species (Nesbitt et al. 1978, Porter and Labisky 1986). Tree species selection can be confounded by tree age and size, presence of a hardwood midstory, and density of trees in the area.

All studies that examined foraging height of Red-cockaded Woodpeckers have reported that males forage higher in trees than females (Hooper and Lennartz 1981, Engstrom and Sanders 1997,
Rudolph et al. 2007). However, in my study this was true of only two of the seven groups and all groups combined. It may not have been apparent that for most of the groups there was no difference in foraging height for males and females if only combined data had been analyzed. Habitat partitioning by foraging height could reduce competition for prey and permit specialization by gender so that trees are used more efficiently. Males are dominant to females and may be using the most productive portions of the foraging substrate.

Porter and Labisky (1986) reported that when Red-cockaded Woodpeckers foraged in stands that were usually avoided, they selected trees of greatest height and dbh. Ramey (1980) detected no significant difference in tree heights used by males and females. I also found there was little difference in tree height selection between males and females. Both strongly preferred taller and avoided shorter trees, probably reflecting the larger, more deeply fissured bark surface area of the taller trees.

Dying and recently dead pine trees, especially those with southern pine beetle (Dendroctonus frontalis), are an important foraging resource for Red-cockaded Woodpeckers, but the reported response by males/females has not been consistent. Hooper and Lennartz (1981), Repasky (1984), and this study found that male and female foraging was similar. Five of the groups and all groups combined in my study had no difference in foraging selection between males and females based on tree condition. Skorupa and MacFarlane (1976), Skorupa (1979), and Repasky (1984) reported that males foraged more frequently than females on dead and dying trees. The differences in the response may reflect the level and occurrence of insect infestations.

Hooper and Lennartz (1981) reported niche overlap between males and females was highest for tree condition (99\%) and dbh (97\%). Most overlap in my study occurred in tree species (99.0\%) and tree condition $(98.3 \%)$. Foraging height overlap was low $(56 \%)$ in the study by Hooper and Lennartz (1981), but was $87.8 \%$ in my study. Higher niche overlap for foraging height and also similarity in foraging height for five of the seven groups in my study reflected the considerably younger forest than that studied by Hooper and Lennartz (1981) where there was less opportunity for vertical divergence in foraging height between males and females. 
Hanula et al. (2000) sampled 300 living pine trees at SRS during the same time frame in which my study was conducted and found that arthropod biomass/tree increased with increasing stand age up to $\sim 65-70$ years, but the arthropod biomass/ha was highest in the youngest stands. Abundance and biomass of arthropods on each tree trunk was positively correlated with bark thickness and tree diameter, and negatively correlated with basal area $\left(\mathrm{m}^{2} / \mathrm{ha}\right)$. There was no correlation of diversity, abundance, or biomass with arthropods on the tree trunk with site index, numbers of herbaceous plant genera in the understory, number of herbaceous plant stems, or percent ground cover by herbs. The characteristics of the stands, including average bark thickness and dbh, associated with greater arthropod abundance and biomass on the bark are positively correlated with tree age, but are subject to change depending on how stands are managed (Hanula et al. 2000). Current management guidelines at SRS include prescribed burning at least 2-3 times/10 years in active Red-cockaded Woodpecker clusters, midstory tree/shrub removal, thinning of overstory pines, suppression of pine beetle infestations, and extensive recommendations for regeneration (Edwards et al. 2000).

Hooper and Lennartz (1981) and Zwicker and Walters (1999) reported Red-cockaded Woodpeckers preferentially selected the largest trees with respect to dbh with no differences between males and females. My results were similar for five of the groups and for all groups combined. Both males and females consistently selected larger dbh trees based on availability, far more than expected on the basis of their presence in the habitat. Larger trees have more arboreal surface area available in which to forage per visit and probably richer resource patches/unit area than smaller trees.

All researchers who have investigated individual tree selection have found that large old trees are preferred over smaller, younger ones (DeLotelle et al. 1987, Jones and Hunt 1996, Hardesty et al. 1997, Walters et al. 2002). Age and size of pine trees are highly correlated until about age 80 (Platt et al. 1988). It is not clear whether tree size (dbh), age, or both is the more important determinant of tree selection by foraging Redcockaded Woodpeckers. There was a significant difference between males and females in my study in mean tree age selected in four of the groups and in all groups combined; however, it was not always the same gender that had the stronger selection for older trees. Females tended to select trees with higher dbh values. Females spend more time foraging on the trunks than males, and it is likely this difference reflects females taking advantage of the additional foraging surface area provided on larger trees. Both males and females avoided foraging in trees $<30$ years of age with some groups not using them. There was a strong preference by both males and females to use trees at least 60 years of age in my study. Males and females still preferred to forage on older trees even though a majority of stands at SRS were considered young.

There was little difference in dbh size among the pines at the SRS, but longleaf pines on average were strongly preferred as foraging substrate by both males and females. Loblolly, the second most commonly available pine species within the home ranges next to longleaf pine, tended to be selected against. The mean age of longleaf pine in some groups exceeds that of loblolly pine, but in other groups the opposite is true. Males (69.4\% of observations) and females (72.7\% of observations) strongly selected longleaf pine trees in relation to the predicted use of longleaf pine $(46.2 \%)$. Red-cockaded Woodpeckers evolved in a mixed-age forest containing only a relatively small proportion of young pine trees (Frost 1993) and in a landscape dominated by longleaf pine; thus, they may be more adapted to foraging on surfaces of old, large pine trees. It is logical to assume they are best equipped morphologically and behaviorally to use longleaf pine. The strong preference by both males and females to use longleaf pine does not appear to be strictly the result of tree size or age.

Habitat segregation observed in foraging Redcockaded Woodpeckers may be designed to reduce competition between males and females to allow more efficient use of the available foraging habitat. The more socially dominant males may cause females to use less productive areas. It is plausible that partitioning by gender in this species may be an efficient mechanism to facilitate cohesion of the group by reducing male/ female competition and aggression. Breeding males at SRS tended to hold their territories until they disappeared (and were presumed dead). Females were more flexible in maintaining their pair bonds. Thus, it would be beneficial to the group to minimize aggressive encounters and to maximize social cohesion of group members. This 
may be the mechanism that developed differences between males and females as documented at this younger growth site and elsewhere.

Red-cockaded Woodpecker mean reproductive success (fledglings/pair) at SRS ranged from 1.4 to 3.4 with the highest rates $(2.8-3.4)$ observed for groups with at least 10,000 pine stems $\geq 25.4 \mathrm{~cm}$ dbh within $800 \mathrm{~m}$ of the nest cavity (Franzreb 2004). Reproductive success was significantly related to number of available pine stems $\geq 25.4 \mathrm{~cm} \mathrm{dbh}$ (Franzreb 2004). Typical mean reproductive rates in other parts of the range were 1.34-1.67 fledglings/pair (Conner et al. 2001). Higher rates at SRS, rather than due mainly to habitat quality, are possibly the result of the unusually intensive management of the species on the site, including installation of artificial cavity inserts, removal of cavity competitors, translocating birds to re-establish a pair where one member has been lost, frequent monitoring of cavities to detect damage to artificial inserts, and frequent monitoring of all individuals in the population (Franzreb 2004).

Subsequent to initiation of these management activities, the population level has increased to $\sim 196$ adults and fledglings in 2006 (John Blake, pers. comm.) from a low of four birds in 1986 (Franzreb 1997). Development of the technique to install artificial cavity inserts for the Redcockaded Woodpecker was pioneered at SRS (Allen 1991) and installation of these devices has been a widely used management tool in many parts of the range. Artificial inserts at SRS were used by $47 \%$ of the birds in comparison to $53 \%$ that used naturally excavated cavities for the nest location during my study (K. E. Franzreb, unpubl. data). It is likely that Red-cockaded Woodpeckers would not have persisted at SRS without the assistance provided by these management actions.

Current federal guidelines for managing Redcockaded Woodpecker foraging habitat are complex and address factors including type of forest regeneration, rotation age, basal area, and homerange size needed per group (USFWS 2003). Management and recovery of the Red-cockaded Woodpecker have focused on providing suitable foraging habitat in more mature and older pine stands than typically found at SRS. The results of my study indicate that younger forest stands, as long as they are at least 30 years of age, may provide acceptable foraging habitat and should not automatically be regarded as unacceptable or sub-optimal.
Younger trees (preferably at least $40 \mathrm{~cm} \mathrm{dbh)} \mathrm{in}$ which managers have either installed artificial cavity inserts or drilled cavities are necessary to provide for nesting and night roosting if older trees are insufficient for natural cavity excavation. It is preferable to provide trees of sufficient size so birds can create their own cavities rather than rely on artificial inserts. Allowing pines to age to $\geq 60$ years, preferably even older, provides better foraging habitat and trees of sufficient size for birds to excavate their own cavities. Maintaining the site in just young pines will not maintain a self-sustaining population without continued intensive management actions as there will be insufficient trees for natural cavity excavation nor would there be the larger trees that are preferred for foraging. The need to provide larger, older pines has been recognized in the SRS management plan for the Red-cockaded Woodpecker, which calls for a number of proactive actions including a rotation age of 120 and 100 years for longleaf pine and loblolly pine stands, respectively, in the main Red-cockaded Woodpecker management area (Edwards et al. 2000). Older pines will be optimal foraging substrate for both male and female Red-cockaded Woodpeckers and will provide the large trees needed for natural cavity excavation.

\section{ACKNOWLEDGMENTS}

This research was funded by the Department of Energy, SRS, through the USDA Forest Service Savannah River under Interagency Agreement DE-IA09-76SR00056 and is gratefully acknowledged. I am especially grateful to Steven Schulze for field support and for generating the data bases to handle a large volume of behavioral and vegetation data. I also thank my field staff whose support has been crucial to the success of the Red-cockaded Woodpecker research at the site. I thank C. H. Greenberg, J. A. Jackson, D. C. Rudolph, and John Blake for reviewing the manuscript and Stan Zarnoch for statistical review. The cooperation of the USDA Forest Service Savannah River is gratefully acknowledged (John Irwin, Elizabeth LeMaster, William Jarvis, Glenn Gaines, and David Wilson). In particular, I thank John Blake, Savannah River Forest Station, for his long-standing support of my research on the site.

\section{LITERATURE CITED}

Allen, D. H. 1991. An insert technique for constructing artificial Red-cockaded Woodpecker cavities. USDA, Forest Service, General Technical Report SE-73. Southeastern Forest Experiment Station, Asheville, North Carolina, USA.

Conner, R. N., D. C. Rudolph, And J. R. Walters. 2001. The Red-cockaded Woodpecker: surviving in a fire- 
maintained ecosystem. University of Texas Press, Austin, USA.

Delotelle, R. S., J. R. Newman, and A. E. Jerauld. 1983. Habitat use by Red-cockaded Woodpeckers in central Florida. Pages 59-67 in Proceedings of the Red-cockaded Woodpecker Symposium, II (D. A. Wood, Editor). Florida Game and Fresh Water Fish Commission, Tallahassee, USA.

Delotelle, R. S., R. J. Epting, and J. R. Newman. 1987. Habitat use and territory characteristics of Redcockaded Woodpeckers in central Florida. Wilson Bulletin 99:202-217.

Edwards, J. W., W. M. SMAthers JR., E. T. Lemaster, AND W. L. JARVIS. 2000. Savannah River Site Redcockaded Woodpecker management plan. USDA, Forest Service, Unpublished Report. Savannah River Forest Station, New Ellenton, South Carolina, USA.

ENGSTROM, R. T. AND F. J. SANDERS. 1997. Red-cockaded Woodpecker foraging ecology in an old-growth longleaf pine forest. Wilson Bulletin 109:203-217.

FrANZREB, K. E. 1997. Success of intensive management of a critically imperiled population of Red-cockaded Woodpeckers in South Carolina. Journal of Field Ornithology 68:458-470.

FRANZREB, K. E. 1999. Factors that influence translocation success in the Red-cockaded Woodpecker. Wilson Bulletin 111:38-45.

FRANZREB, K. E. 2004. Habitat preferences of foraging Red-cockaded Woodpeckers at the Savannah River Site, South Carolina. Pages 553-561 in Red-cockaded Woodpecker: road to recovery (R. Costa and S. J. Daniels, Editors). Hancock House Publishers, Blaine, Washington, USA.

Frost, C. C. 1993. Four centuries of changing landscape patterns in the longleaf pine ecosystem. Proceedings of the Tall Timbers Fire Ecology Conference 18:17-44.

Hanula, J. L., K. E. Franzreb, and W. D. Pepper. 2000. Longleaf pine characteristics associated with arthropods available for Red-cockaded Woodpeckers. Journal of Wildlife Management 64:60-70.

Hardesty, J. L., K. E. Gault, and R. P. Percival. 1997. Ecological correlates of the Red-cockaded Woodpecker (Picoides borealis) foraging preferences, habitat use, and home range size in northwest Florida (Eglin Air Force Base). Final Report, Research Work Order 99. Florida Cooperative Fish and Wildlife Research Unit, University of Florida, Gainesville, USA.

HeJl, S. J., J. Verner, AND G. W. Bell. 1990. Sequential versus initial observations in studies in avian foraging. Studies in Avian Biology 13:166-173.

HeLMS, J. A. (Editor). 1998. The dictionary of forestry. Society of American Foresters, Bethesda, Maryland, USA.

Hooper, R. G. AND M. L. LenNARTZ. 1981. Foraging behavior of the Red-cockaded Woodpecker in South Carolina. Auk 98:321-334.

JACKSON, J. A. 1986. Biopolitics, management of federal lands, and the conservation of the Red-cockaded Woodpecker. American Birds 40:1162-1168.

JACKSON, J. A., M. R. LENNARTZ, AND R. L. HoOper. 1979. Tree age and cavity initiation by Red-cockaded Woodpeckers. Journal of Forestry 77:102-103.
JAMES, F. AND H. SHUGART. 1970. A quantitative method of habitat description. Audubon Field Notes 24:727-736.

JoNES, C. M. AND H. E. HuNT. 1996. Foraging habitat of the Red-cockaded Woodpecker on the D'Arbonne National Wildlife Refuge, Louisiana. Journal of Field Ornithology 67:511-518.

Levins, R. 1968. Evolution in changing environments. Princeton University Press, Princeton, New Jersey, USA.

LiGon, J. D. 1968. Sexual differences in foraging behavior in two species of Dendrocopos woodpeckers. Auk 85:203-215.

Ligon, J. D., P. B. Stacey, R. N. CONNER, C. E. Bock, AND C. S. AdKISSON. 1986. Report of the American Ornithologists' Union Committee for the conservation of the Red-cockaded Woodpecker. Auk 103:848-855.

Mengel, R. M. AND J. JACKSON. 1977. Geographic variation of the Red-cockaded Woodpecker. Condor 79:349-355.

Nesbitt, S. A., D. T. Gilbert, And D. B. Barbour. 1978. Red-cockaded Woodpecker fall movements in a Florida flatwoods community. Auk 95:145-151.

Pizzoni-Ardemani, A. 1990. Sexual dimorphism and geographic variation in the Red-cockaded Woodpecker. Thesis. North Carolina State University, Raleigh, USA.

Platt, W. J., G. W. Evans, and S. L. Rathburn. 1988. The population dynamics of a long-lived conifer (Pinus palustris). American Naturalist 131:491-525.

Porter, M. L. AND R. F. LABISKY. 1986. Home range and foraging habitat of Red-cockaded Woodpeckers in northern Florida. Journal of Wildlife Management 50:239-247.

Porter, M. L., M. W. Collopy, R. F. LABisky, AND R. C. LITTELL. 1985. Foraging behavior of Red-cockaded Woodpeckers: an evaluation of research methodologies. Journal of Wildlife Management 49:505-507.

RAMEY, P. 1980. Seasonal, sexual, and geographic variation in the foraging ecology of Red-cockaded Woodpeckers (Picoides borealis). Thesis. Mississippi State University, Starkville, USA.

RAO, J. N. K. AND A. J. SCOTT. 1992. A simple method for the analysis of clustered binary data. Biometrics 48:577-585.

REPASKY, R. R. 1984. Home range and habitat utilization of the Red-cockaded Woodpecker. Thesis. North Carolina State University, Raleigh, USA.

Rudolph, D. C, R. N. Conner, R. S. Schaefer, AND N. E. KOERTH. 2007. Red-cockaded Woodpecker foraging behavior. Wilson Journal of Ornithology 119:170-180.

SAS Institute InC. 2004. SAS/STAT 9.1. User's guide. SAS Institute Inc., Cary, North Carolina, USA.

SCHOENER, T. W. 1970. Non-synchronous spatial overlap of lizards in patchy environments. Ecology 51:408-418.

SkORUPA, J. P. 1979. Foraging ecology of the Redcockaded Woodpecker in South Carolina. Thesis. University of California, Davis, USA.

Skorupa, J. P. AND R. W. McFarlane. 1976. Seasonal variation in foraging territory of Red-cockaded Woodpeckers. Wilson Bulletin 88:662-665.

U.S. FISH AND WILDLIFE SERVICE (USFWS). 2003. Recovery Plan for the Red-cockaded Woodpecker (Picoides 
borealis). Second Revision. USDI, Fish and Wildlife Service. Southeast Region, Atlanta, Georgia, USA.

WAHLENBERG, W. G. 1960. Loblolly pine: its use, ecology, regeneration, protection, growth and management. Duke University School of Forestry, Durham, North Carolina, USA.

WALters, J. R. 1990. Red-cockaded Woodpecker: a 'primitive' cooperative breeder. Pages 69-101 in Cooperative breeding in birds (P. B. Stacey and W. D. Koenig, Editors). Cambridge University Press, London, United Kingdom.

Walters, J. R., S. J. Daniels, J. H. CARTer III, And P. D. DOERR. 2002. Defining quality of Red-cockaded
Woodpecker foraging habitat based on habitat use and fitness. Journal of Wildlife Management 66:10641082.

Walters, J. R., S. J. Daniels, J. H. Carter III, P. D. Doerr, K. Brust, AND J. M. Mitchell. 2000. Foraging habitat resources, preferences and fitness of Red-cockaded Woodpeckers in the North Carolina sandhills. Fort Bragg Project Final Report. Virginia Polytechnic Institute and State University, Blacksburg, and North Carolina State University, Raleigh, USA.

ZWICKER, S. M. AND J. R. WALters. 1999. Selection of pines for foraging red-cockaded woodpeckers. Journal of Wildlife Management 63:843-852. 